\section{Kidney \\ Blood Pressure Research}

\title{
Acute Kidney Injury in a Single Pediatric Intensive Care Unit in Poland: A Retrospective Study
}

\author{
Monika Miklaszewska ${ }^{a}$ Przemysław Korohoda ${ }^{b}$ Alina Sobczak ${ }^{c}$ \\ Anna Horbaczewskac Agata Filipiak ${ }^{c}$ Katarzyna Zachwieja ${ }^{a}$ Krzysztof Kobylarz ${ }^{d}$ \\ Marcin Tkaczyk ${ }^{\mathrm{e}}$ Dorota Drożdża Jacek A. Pietrzyk ${ }^{\mathrm{a}}$
}

aDepartment of Pediatric Nephrology, Jagiellonian University Medical College; ${ }^{b}$ AGH University of Science and Technology, Department of Electronics, Faculty of Computer Science, Electronics and Telecommunications; ' $2^{\text {nd }}$ Students' Scientific Group by Dialysis Department, Students' Scientific Society Jagiellonian University Collegium Medicum; 'Department of Anesthesiology and Intensive Care, PolishAmerican Institute of Pediatrics, Jagiellonian University Medical College, Kraków; eNephrology Division, Polish Mothers Memorial Hospital Research Institute, Łódź, Poland

\section{Key Words}

Acute kidney injury $•$ Children $•$ Pediatric intensive care $•$ Urine output

\begin{abstract}
Background/Aims: The recent improvements of management of patients in pediatric intensive care units (PICU) are associated with improved outcome. However, this decrease in mortality is associated with an increased number of children with acute kidney injury (AKI), especially in patients with multiorgan failure. Methods: The report presents a retrospective analysis of 25 cases of AKI (assessed based on the pRIFLE criteria) in PICU within 7 years. Results: AKI was diagnosed in $1.24 \%$ of all hospitalized children. AKI percentage duration (as compared to the total hospitalization time) in the children who died vs. the survivors was $79.55 \%$ vs. $46.19 \%$, respectively ( $p<0.05$ ). The mortality rate of AKI patients was $40 \%$ which was 4.4-times higher as compared to the total mortality rate in PICU. The final cumulative survival ratio (FCSR) of patients meeting the oliguria criterion (which was met in $48 \%$ of AKI patients) was $37 \%$ vs. $49 \%$ in non-oliguric children. Averaged urine output values in the first week of hospitalization in the deceased vs. survivors were 1.49 vs. $2.57 \mathrm{ml} / \mathrm{kg} / \mathrm{h}$, respectively $(p<0.05)$. Conclusions: Oliguria should not be considered as a sensitive parameter for AKI diagnosing in children below one year of age. A decreased mean urine output in the first week of PICU hospitalization (less than $1.4 \mathrm{ml} / \mathrm{kg} / \mathrm{h}$ ) should be considered as a poor prognostic factor. In many cases AKI was diagnosed too infrequently and too late.
\end{abstract}




\section{Kidney \\ Blood Pressure Research}

\section{Introduction}

Commonly available, effective, but at the same time increasingly more aggressive therapeutic methods are associated with an increase the number of patients hospitalized in pediatric intensive care units (PICU). Furthermore, the risk of AKI associated with those medical procedures and of nephrotoxic medications may be increased. This phenomenon resulted to an increased number of patients with AKI, however, the precise incidence rate of this complication has been reported only in approximate values [1].

The majority of documented cases of AKI in pediatric patients described children who had already developed renal failure (stage F) and required renal replacement therapy (RRT) [2-5]. Nevertheless, the results of recent studies indicate that a low increase in serum creatinine ( $\mathrm{SCr}$ ), amounting only to $10 \%-24 \%$, was positively correlated with duration of hospitalization and cost of treatment and was an independent factor of morbidity and mortality risk both in adult patients and in children [6, 7].

\section{Material and Methods}

The objective of the present study was a retrospective analysis of AKI in PICU patients, taking into consideration epidemiology and prevalence of diagnosing this complication depending on the definition employed. Furthermore, a number of diagnostic parameters were meticulously evaluated as potential predictors of mortality. Data from such studies might be crucial for the development of an diagnostictherapeutic algorithm for AKI pediatric patients allowing an early identification of high risk groups. The early diagnosis of AKI will lead to immediate therapeutic interventions before the development of loss of renal function (stage $\mathrm{L}$ ) or end stage renal disease (stage E) $[1,8,9]$.

The study included 25 children (8 newborns, 8 infants, 9 older children) hospitalized in PICU of the University Children's Hospital of Cracow, Poland in the period between January 1st, 2006 and December 31st, 2012. The medical records of these patients featured the ICD10 N17 code (AKI). All children had bladder catheters and their hourly urine output (UO) was monitored.

In the present study, a change in the prevalence of AKI diagnosing depending on the employed definition of "zero point", which assessed the initial kidney function, was analyzed. In all patients, the diagnosis of AKI was established employing the pRIFLE scale criteria [10], with the initial values of SCr or eGFR determined by the following methods:

I. In the newborn group, the "zero point" for the pRIFLE scale was determined based on SCr and eGFR (SCrN, eGFRN) values depending on gestational and chronological age $[11,12]$,

II. In the infant group, the "zero point" for the pRIFLE scale was determined based on:

1. SCr value calculated for age according to the following equation: $\mathrm{SCr}=(0.18+0.032 \times$ age $) \times 88.4$ [13],

2. minimum SCr value for age $(6 \mu \mathrm{mol} / \mathrm{l})$ [14],

3. maximum SCr value for age of 1-23 months (23 $\mu \mathrm{mol} / \mathrm{l})$ [14],

4. eGFR value calculated according to the one-marker formula developed by Pottel et al. [15] from the creatinine concentration value on the first or second day of hospitalization or up to 3 months before hospitalization.

III. In the group of older children, the "zero point" for the pRIFLE scale was determined based on:

1. SCr value calculated for age [13],

2. minimum SCr value for age $(6 \mu \mathrm{mol} / 1)$ [14],

3. maximum SCr value for a given age (age/SCr: 1-6 years: $57 \mu \mathrm{mol} / \mathrm{l} ; 7-12$ years: $74 \mu \mathrm{mol} / \mathrm{l}$;

13-18 years: $100 \mu \mathrm{mol} / \mathrm{l}$ ) [14],

4. initial eGFR value determined at the $100 \mathrm{ml} / \mathrm{min}$ level.

Additionally, in all the age groups, AKI was diagnosed based on the hourly UO value according to the pRIFLE scale. 


\section{Kidney Blood Pressure Research}

Kidney Blood Press Res 2014;39:28-39

DOI: 10.1159/000355774

Publisned onIIne: IVlay 09, 2014

C 2014 S. Karger AG, Base

www.karger.com/kbr

The statistical description of the results and comparative analysis of their distribution were performed using respectively: the mean value, range, standard deviation, median value, first and third quartiles, t-Student test and - in view of the lack of certainty as to all the investigated groups meeting the assumptions of the t-Student test - the rank sum Wilcoxon test. In addition, the ROC curve analysis was performed, resulting in calculating the area under the curve and establishing the cut-off point, for which the following values were determined: the LR coefficient (at the same time constituting the odds ratio) as well as sensitivity and specificity. The survival analysis was performed using the Kaplan-Meier curves with the log-rank test, Cox-Mantel test and Gehan generalized Wilcoxon test. The significance of the difference between two-stage distributions was assessed by the one-sided Fisher's exact test. The calculations were performed using the Matlab package (MATLAB and Statistics Toolbox Release 2013a, The MathWorks, Inc., Natick, Massachusetts, USA) and verified by the STATISTICA package (V. 10, StatSoft, Inc., www.statsoft. com). The threshold value of $\mathrm{p}=0.05$ was adopted while assessing statistical significance.

\section{Results}

The most common primary diagnoses established in the analyzed population of children with AKI were hemato-oncologic diseases; AKI with a nephrologic background was diagnosed in a single patient only. The most frequent coexisting diagnosis, secondary to the primary disease, was multiorgan failure (MOF). Nephrologic causes were noted in two cases only (i.e. autosomal recessive polycystic kidney disease as a primary diagnosis and one kidney necrosis accompanying necrotizing enterocolitis as coexisting diagnosis). Cardiac diseases were the most common primary causes of AKI in the group of newborns, while hemato-oncologic diseases predominated in the group of older children. Table 1 presents the primary and secondary diagnoses noted in the analyzed population.

The mean duration of hospitalization in PICU of the child with AKI was 35 days, with newborns being hospitalized for the longest period and the duration of hospitalization decreasing in the older age groups (Figure 1 ).

All the newborns and infants were on mechanical ventilatory support, while mechanical ventilation was required by $78 \%$ of the older children. The longest period of ventilatory support was required by the newborns, but in the analysis of the percentage of mechanical ventilation days $v s$. the entire hospitalization period in PICU, no significant differences were demonstrated between particular age groups. The majority of children required parenteral nutrition. Table 2 presents detailed clinical data of the children hospitalized in PICU.

Nephrotoxic aminoglycosides were employed in two children only, with the mean treatment duration of 7 days. Vancomycin was also rarely administered. Loop diuretics were used in all the children; no difference was noted in the percentage of duration of loop diuretics administration vs. the entire hospitalization in PICU for particular age groups. The longest time of using dopaminergic medications, adrenaline and noradrenaline was observed in the group of newborns; there was a tendency towards shortening the duration of administration of the above pharmaceuticals in older age groups. ACE inhibitor (enalapril) was used in 9 patients (36\%), including 4 newborns (50\%), which was the consequence of the highest prevalence of cardiac diseases as the cause of AKI in this age group. One-half newborns required cardiac surgery which took place from 9-th to 18-th day of PICU stay.

The mean minimum urine output in the investigated group of children was $0.82 \mathrm{ml} /$ $\mathrm{kg} / \mathrm{h}$, with the group of newborns demonstrating nonoliguric AKI (UO $1.19 \mathrm{ml} / \mathrm{kg} / \mathrm{h}$ ). The phenomenon of nonoliguric AKI in newborns was also confirmed by the analysis of the mean urine output in the first week of hospitalization, which in this age group equaled $2.65 \mathrm{ml} /$ $\mathrm{kg} / \mathrm{h}$ (as compared to $1.4 \mathrm{ml} / \mathrm{kg} / \mathrm{h}$ in the older children). The mean onset time of oliguria (defined as UO below $0.5 \mathrm{ml} / \mathrm{kg} / \mathrm{h} /$ minimum 16 hours; pRIFLE stage I - injury) was on day 5 of hospitalization. The mean time of determining creatinine concentration in PICU patients was day 2 of hospitalization.

Stage F - failure - was noted in $84 \%$ of the investigated children, with the prevalence being $75 \%$ in newborns and infants and $100 \%$ in older children. The mean time of detect- 


\section{Kidney \\ Blood Pressure Research}

ing stage I was day 3 of hospitalization, while for stage $\mathrm{F}$, the detection occurred on day 4.

Renal replacement therapy (RRT) was required by one-half of the children; the mean RRT duration was 11.4 days (or $32.6 \%$ of the total hospitalization in PICU). The most frequently employed methods were peritoneal dialysis (50\%) and continuous dialysis techniques (25\%).

The mean duration of AKI in the investigated group of children was 12.2 days, what equaled $60 \%$ of the total hospitalization time in PICU. The longest duration of AKI was noted in the group of newborns (20 days), being equal to $50 \%$ of their hospitalization time in PICU. Table 3 presents a detailed characterization of kidney function in the analyzed population.

While analyzing the prevalence of establishing the diagnosis of AKI depending on the
Table 1. Prevalence and type of primary and secondary diagnoses in the studied pediatric population

\begin{tabular}{|c|c|c|}
\hline Primary diagnosis & Age group & $\begin{array}{l}\text { Number of } \\
\text { diagnoses }\end{array}$ \\
\hline \multirow[t]{3}{*}{ Hemato - oncologic diseases } & Infants & 3 \\
\hline & Older children & 6 \\
\hline & Total & 9 \\
\hline \multirow[t]{4}{*}{ Cardiologic diseases } & Newborns & 4 \\
\hline & Infants & 3 \\
\hline & Older children & 1 \\
\hline & Total: & 8 \\
\hline \multirow[t]{4}{*}{ Gastroenterological diseases } & Newborns & 3 \\
\hline & Infants & 2 \\
\hline & Older children & 1 \\
\hline & Total & 6 \\
\hline Nephrologic diseases & Newborns & 1 \\
\hline $\begin{array}{l}\text { Rheumatologic diseases: } \\
\text { Juvenile Idiopathic Arthritis (JIA) }\end{array}$ & Older children & 1 \\
\hline $\begin{array}{l}\text { Most common coexisting diagnoses } \\
\text { (excluding AKI) * }\end{array}$ & Age group & $\begin{array}{l}\text { Number of } \\
\text { diagnoses }\end{array}$ \\
\hline \multirow[t]{4}{*}{ Multi Organ Failure (MOF) } & Newborns & 1 \\
\hline & Infants & 5 \\
\hline & Older children & 8 \\
\hline & Total & 14 \\
\hline \multirow[t]{4}{*}{ Others** } & Newborns & 4 \\
\hline & Infants & 5 \\
\hline & Older children & 4 \\
\hline & Total & 13 \\
\hline \multirow[t]{4}{*}{ Respiratory and circulatory failure (RCF) } & Newborns & 6 \\
\hline & Infants & 2 \\
\hline & Older children & 3 \\
\hline & Total & 9 \\
\hline \multirow[t]{4}{*}{ Sepsis } & Newborns & 4 \\
\hline & Infants & 2 \\
\hline & Older children & 2 \\
\hline & Total & 8 \\
\hline \multirow[t]{3}{*}{ Gastroenterological diseases } & Newborns & 1 \\
\hline & Older children & 3 \\
\hline & Total & 4 \\
\hline Cardiologic diseases & Newborns & 3 \\
\hline Nephrologic diseases & Newborns & 1 \\
\hline
\end{tabular}

$*$ a given patient frequently had several secondary diagnoses,

** Other diagnoses: Newborns: Down's syndrome, Di George syndrome, neonatal hypoglycemia, prematurity. Infants: Down's syndrome, CMV infection, low T3 syndrome, intracerebral hemorrhage, ischemic stroke. Older children: intracerebral hematoma, abnormal metabolism of branched-chain amino acids (methylmalonic acidemia), pulmonary hemosiderosis, diabetes

employed method of determining the initial value of SCr or eGFR to be used in the pRIFLE scale in a given age group, the authors demonstrated that AKI could have been diagnosed in every case, regardless of the selected method of determining the "zero point". On the other hand, the criteria of the value of hourly urine output classified as oliguria (stage I according to pRIFLE; UO $<0.5 \mathrm{ml} / \mathrm{kg} / \mathrm{h} / \mathrm{min} .16$ hours) - as the prerequisite of AKI diagnosis establishment - were met by $12(48 \%)$ of the children (25\% of newborns, $50 \%$ of infants and $66.7 \%$ of older children). The data confirmed the observation of nonoliguric AKI in the population of newborns and infants. Table 4 presents particular methods of diagnosing AKI in the group of the analyzed children. 


\section{Kidney Blood Pressure Research}

Fig. 1. The median and interquartile range of the duration of hospitalization in PICU depending on the age group. The whiskers indicate the whole range for each group.

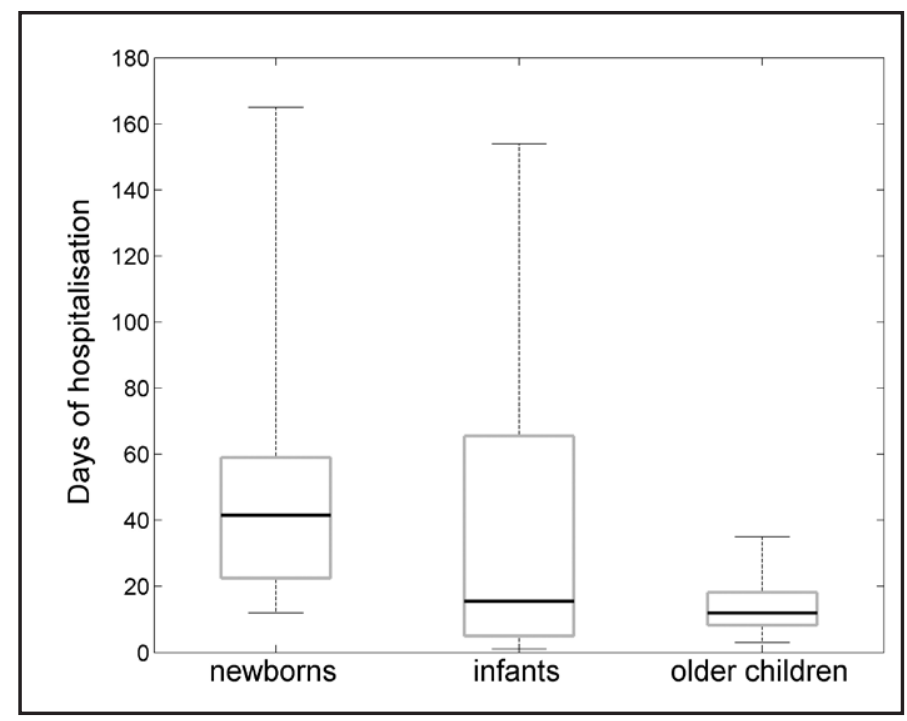

Table 2. Clinical characterization of the pediatric study population

\begin{tabular}{|c|c|c|c|c|}
\hline Age group & Newborns & Infants & Older children & Total \\
\hline Mean age [months] +/- SD [range] & $\begin{array}{l}0.16+/-0.24 \\
{[0-0.75]}\end{array}$ & $\begin{array}{l}6.94+/-3.80 \\
{[1-11]}\end{array}$ & $\begin{array}{l}148.00+/-64.63 \\
{[40-236]}\end{array}$ & $\begin{array}{l}55.55+/-80.08 \\
{[0-236]}\end{array}$ \\
\hline Mean body mass $[\mathrm{kg}]+/-$ SD [range] & $\begin{array}{c}3.1+/-1.0 \\
{[1.7-4.7]}\end{array}$ & $\begin{array}{l}5.8+/-1.7 \\
{[2.6-7.4]}\end{array}$ & $\begin{array}{c}39.3+/-16.2 \\
{[18.0-65.0]}\end{array}$ & $\begin{array}{c}17.0+/-19.5 \\
{[1.7-65.0]}\end{array}$ \\
\hline Mean number of days in PICU +/-SD [range] & $\begin{array}{l}52.9+/-48.8 \\
{[12-165]}\end{array}$ & $\begin{array}{c}40.9+/-57.7 \\
{[1-154]}\end{array}$ & $\begin{array}{l}14.0+/-9.9 \\
{[3-35]}\end{array}$ & $\begin{array}{l}35.0+/-44.5 \\
{[1-165]}\end{array}$ \\
\hline $\begin{array}{l}\text { Number and }(\%) \text { of children } \\
\text { on mechanical ventilatory support }\end{array}$ & $8(100 \%)$ & $8(100 \%)$ & $7(78 \%)$ & $23(92 \%)$ \\
\hline Mean number of days of ventilatory support +/-SD [range] & $\begin{array}{c}16.9+/-12.1 \\
{[3-41]}\end{array}$ & $\begin{array}{c}8.9+/-7.8 \\
{[1-21]}\end{array}$ & $\begin{array}{c}14.1+/-10.2 \\
{[3-33]}\end{array}$ & $\begin{array}{c}13.3+/-10.3 \\
{[1-41]}\end{array}$ \\
\hline Mean \% of ventilatory support vs. & $49.1 \%$ & $67.3 \%$ & $85.6 \%$ & $66.5 \%$ \\
\hline days of hospitalization in PICU [range] & {$[5.8-100]$} & {$[0.6-100]$} & {$[58.3-100]$} & {$[0.6-100]$} \\
\hline Mean number and (\%) of children on TPN & $7(87.5 \%)$ & $8(100 \%)$ & $7(78 \%)$ & $22(88 \%)$ \\
\hline Mean number of days of TPN employment +/-SD; [range] & $\begin{array}{l}15.1+/-6.2 \\
{[5-21]}\end{array}$ & $\begin{array}{l}10.1+/-8.9 \\
{[1-21]}\end{array}$ & $\begin{array}{l}9.3+/-8.1 \\
{[1-21]}\end{array}$ & $\begin{array}{l}11.5+/-7.9 \\
{[1-21]}\end{array}$ \\
\hline Outcome: transfer to a pediatric ward & $6(75 \%)$ & $4(50 \%)$ & $5(55.5 \%)$ & $15(60 \%)$ \\
\hline Outcome: death & $2(25 \%)$ & $4(50 \%)$ & $4(45.5 \%)$ & $10(40 \%)$ \\
\hline
\end{tabular}

Table 3. Detailed characterization of kidney function in the analyzed population of children

\begin{tabular}{|c|c|c|c|c|}
\hline & Newborns & Infants & Older children & Total \\
\hline $\begin{array}{l}\text { Mean UO } \min [\mathrm{ml} / \mathrm{kg} / \mathrm{h}]+/-\mathrm{SD} \\
\text { [range] }\end{array}$ & $\begin{array}{c}1.19+/-0.87 \\
{[0-2.50]}\end{array}$ & $\begin{array}{c}0.62+/-0.67 \\
{[0-1.8]}\end{array}$ & $\begin{array}{c}0.64+/-0.84 \\
{[0-2.54]}\end{array}$ & $\begin{array}{c}0.82+/-0.82 \\
{[0-2.54]}\end{array}$ \\
\hline $\begin{array}{l}\text { Mean UO } 1 \text { week }[\mathrm{ml} / \mathrm{kg} / \mathrm{h}]+/-S D \\
\text { [range] }\end{array}$ & $\begin{array}{l}2.65+/-1.45 \\
{[0.05-4.39]}\end{array}$ & $\begin{array}{c}2.46+/-1.37 \\
{[0-4.16]}\end{array}$ & $\begin{array}{c}1.40+/-0.98 \\
{[0-3.10]}\end{array}$ & $\begin{array}{c}2.14+/-1.35 \\
{[0-4.39]}\end{array}$ \\
\hline $\begin{array}{l}\text { pRIFLE: } \mathrm{UO}<0.5 \mathrm{ml} / \mathrm{kg} / \mathrm{h} / \mathrm{min} .16 \\
\text { hours: number of children }(\%)\end{array}$ & $2(25 \%)$ & $4(50 \%)$ & $6(67 \%)$ & $12(48 \%)$ \\
\hline $\begin{array}{l}\text { Mean number of days of AKI } \\
\text { duration +/- SD [range] }\end{array}$ & $\begin{array}{c}20.00+/-10.92 \\
{[5-41]}\end{array}$ & $\begin{array}{c}6.50+/-6.72 \\
{[1-19]}\end{array}$ & $\begin{array}{c}11.22+/-10.92 \\
{[3-35]}\end{array}$ & $\begin{array}{c}12.21+/-10.79 \\
{[1-41]}\end{array}$ \\
\hline $\begin{array}{l}\% \text { of AKI duration } v s . \text { days of } \\
\text { hospitalization in PICU }\end{array}$ & $\begin{array}{c}51.9 \% \\
{[11.5-100]}\end{array}$ & $\begin{array}{c}49.5 \% \\
{[2.6-100 \%]}\end{array}$ & $\begin{array}{c}76.2 \% \\
{[30.0-100 \%]}\end{array}$ & $\begin{array}{c}60.2 \% \\
{[2.6-100 \%]}\end{array}$ \\
\hline \multirow{3}{*}{$\begin{array}{l}\text { Highest pRIFLE stage - number of } \\
\text { children }\end{array}$} & $\mathrm{R}-1$ & $\mathrm{R}-0$ & $\mathrm{R}-0$ & $\mathrm{R}-1$ \\
\hline & $\mathrm{I}-1$ & $\mathrm{I}-2$ & $\mathrm{I}-0$ & I-3 \\
\hline & F-6 & F-6 & F-9 & F-21 (84\%) \\
\hline RRT - number of children (\%) & $4(50 \%)$ & $2(25 \%)$ & $6(66.7 \%)$ & $12(48 \%)$ \\
\hline RRT: PD / HD/ CVVHDF & PD-4 [100\%] & PD-2 [100\%] & $\begin{array}{l}\text { HD-2; CVVHDF-3; } \\
\text { SLEDD-1 }\end{array}$ & $\begin{array}{l}\text { PD-6; CVVHDF-3; } \\
\text { SLEDD-1; HD-2 }\end{array}$ \\
\hline $\begin{array}{l}\text { Mean duration of RRT +/-SD } \\
\text { [range] }\end{array}$ & $\begin{array}{c}8.50+/-8.35 \\
{[1-18]}\end{array}$ & $\begin{array}{c}8.50+/-4.95 \\
{[5-12]}\end{array}$ & $\begin{array}{c}17.33+/-22.95 \\
{[2-63]}\end{array}$ & $\begin{array}{c}12.92+/-16.79 \\
{[1-63]}\end{array}$ \\
\hline
\end{tabular}




\section{Kidney Blood Pressure Research}

Table 4. Methods of diagnosing AKI in the analyzed group of children

\begin{tabular}{|c|c|c|c|}
\hline Age group & $\begin{array}{l}\text { Diagnosis of AKI based on initial point } \\
\text { (zero point): }\end{array}$ & $\begin{array}{l}\text { Number of } \\
\text { children }\end{array}$ & $\begin{array}{l}\text { Averaged day of } \\
\text { diagnosis [range] }\end{array}$ \\
\hline \multirow[t]{3}{*}{ Newborns } & $1-\mathrm{SCrN}$ & $7(100 \%)$ & $3.1[1-7]$ \\
\hline & 2-eGFRN & $7(100 \%)$ & $4.4[1-7]$ \\
\hline & $\mathrm{U} 0<0.5 \mathrm{ml} / \mathrm{kg} / \mathrm{h} / \mathrm{min} .16 \mathrm{hrs}$ & $2(25 \%)$ & $2[1-3]$ \\
\hline \multirow[t]{5}{*}{ Infants } & 3. SCr calculated for age & $8(100 \%)$ & $4.25[1-17]$ \\
\hline & 4. SCr MIN for age ( $6 \mathrm{umol} / \mathrm{l})$ & $8(100 \%)$ & $1.9[1-5]$ \\
\hline & 5. SCr MAX for age of $1-12$ months: $23 \mathrm{umol} / \mathrm{l}$ & $8(100 \%)$ & $5.1[1-8]$ \\
\hline & 6. eGFR for SCr on day $1 / 2$ & $8(100 \%)$ & $5.4[1-17]$ \\
\hline & $\mathrm{UO}<0.5 \mathrm{ml} / \mathrm{kg} / \mathrm{h} / \mathrm{min} .16 \mathrm{hrs}$ & $4(50 \%)$ & $9[2-20]$ \\
\hline \multirow[t]{5}{*}{ Older children } & 3. SCr calculated for age & $9(100 \%)$ & $1.9[1-4]$ \\
\hline & 4. SCr MIN for age (6 umol/l) & $9(100 \%)$ & $1.6[1-3]$ \\
\hline & $\begin{array}{l}\text { 7. SCr MAX for age - older children (age/SCr: } 1-6 \text { years: } 57 \text { umol/l; } \\
\text { 7-12 years: } 74 \text { umol/l; } 13-18 \text { years: } 100 \mathrm{umol} / \mathrm{l} \text { ) }\end{array}$ & $9(100 \%)$ & $3.4[1-16]$ \\
\hline & 8. $\mathrm{GFR}=100 \mathrm{ml} / \mathrm{min}$ & $9(100 \%)$ & $1.9[1-3]$ \\
\hline & $\mathrm{UO}<0.5 \mathrm{ml} / \mathrm{kg} / \mathrm{h} / \mathrm{min} .16 \mathrm{hrs}$ & $6(66.7 \%)$ & $4.7[1-17]$ \\
\hline
\end{tabular}

In the investigated group, $40 \%$ of the children died. The percentage of AKI duration $v s$. the total hospitalization time in PICU was significantly higher in the group of children with a negative outcome $(79.77 \%$ vs. $46.19 \%$; $\mathrm{p}<0.05)$. The deceased children were younger compared to the survivors, however this difference was not statistically significant.

Death, most commonly being a consequence of multiorgan failure (MOF; 6 cases of MOF in a group of 10 deceased children), usually secondary to hemato-oncologic diseases (5/10) occurred on day 19.4. The surviving children revealed the mean PICU hospitalization duration of 45.5 days, hence the resultant longer duration of RRT in this group of patients. These children predominantly suffered from cardiac diseases $(7 / 15)$.

With regard to the survival rate in MOF patients - death occurred in 6/14 (42,3\%) patients with MOF and this incidence was higher (although not statistically significant than that of patients without MOF (4/11, 36\%).

All the deceased children required mechanical ventilatory support, which was employed practically during their entire hospitalization in PICU and was significantly longer with respect to the percentage of ventilatory support $v s$. the total hospitalization time in PICU than in the group of surviving children $(\mathrm{p}=0.001)$. Total parenteral nutrition (TPN) was employed in all the deceased children (mean time: 8.8 days) and in $80 \%$ of the surviving children (mean time: 13.67 days). No differences were noted in the frequency and duration of using dopaminergic medications between the group of deceased children and the survivors. A difference was observed only in the frequency of adrenaline and noradrenaline usage; the medications were employed twice as frequently in the group of the deceased children.

Although the value of hourly UO is not a reliable marker when diagnosing AKI (especially in newborns and infants), nevertheless, its decreased value proved to be an indicator of a poor prognosis. In the group of the deceased children as compared to the surviving patients, not only was the mean minimum value of UO lower by half $(0.52 \mathrm{vs} .1 .00 \mathrm{ml} / \mathrm{kg} / \mathrm{h})$, but also the averaged UO values in the first and second week of hospitalization were lower (1.49 vs. $2.57 \mathrm{ml} / \mathrm{kg} / \mathrm{h}$ and $1.77 v s .2 .76 \mathrm{ml} / \mathrm{kg} / \mathrm{h}$, respectively), with the difference of the minimum UO in the first week being statistically significant $(\mathrm{p}<0.05)$.

Figure 2 presents the Kaplan-Meier survival curves that document the cumulative survival ratio (CSR) of AKI patients in PICU depending on the criterion of oliguria presence (oliguria being defined as UO $<0.5 \mathrm{ml} / \mathrm{kg} / \mathrm{h} / \mathrm{min} .16$ hours). As it follows from the analysis, the final CSR (FCSR) of the patients who had not developed oliguria equaled 49\%, while for children who had met the oliguria criterion, the respective value was only $37 \%$, with the difference being borderline significant ( $p=0.08$ in the log-rank and Cox-Mantel test; $p=0.06$ in the Gehan-Wilcoxon test). 


\section{Kidney Blood Pressure Research}

Figure 3 presents the ROC curve plotted for the number of deaths as depending on the mean value of hourly UO in the first week of hospitalization in PICU. As it follows from the analysis, in the selected cutoff point of the curve equaling $1.4 \mathrm{ml} / \mathrm{kg} / \mathrm{h}$, the likelihood ratio (LR) was 3.75 (at $50 \%$ sensitivity and $87 \%$ specificity). This means that the ratio of the deceased children to the surviving children following the application of the condition describing the UO value as $<1.4 \mathrm{ml} / \mathrm{kg} / \mathrm{h}$ in comparison to the same ratio in the studied population increased 3.75 times.

As it has been already mentioned, the risk of death in the studied population was $40 \%$, but the same risk in children, in whom the mean UO in the first week of hospitalization in PICU had not exceeded $1.4 \mathrm{ml} / \mathrm{kg} / \mathrm{h}$ was $71 \%$ (PPV=0.71), and thus, the risk increased in the patients indicated by the test by a factor of 1.8 .

The high prognostic value of UO was also supported by the fact that a difference was observed in the oliguria criterion as the prerequisite of diagnosing AKI $(0.5 \mathrm{ml} / \mathrm{kg} / \mathrm{h} /$ min. 16 hours - stage I), the difference being seen in $70 \%$ of the subjects in the group of the deceased children and only in $33 \%$ of the surviving children. However this difference was not reaching significance $(p=0.08$, Fisher's exact test), possibly due to the small number of patients. Table 5 presents a comparison of selected clinical parameters of the surviving children vs. the deceased patients.

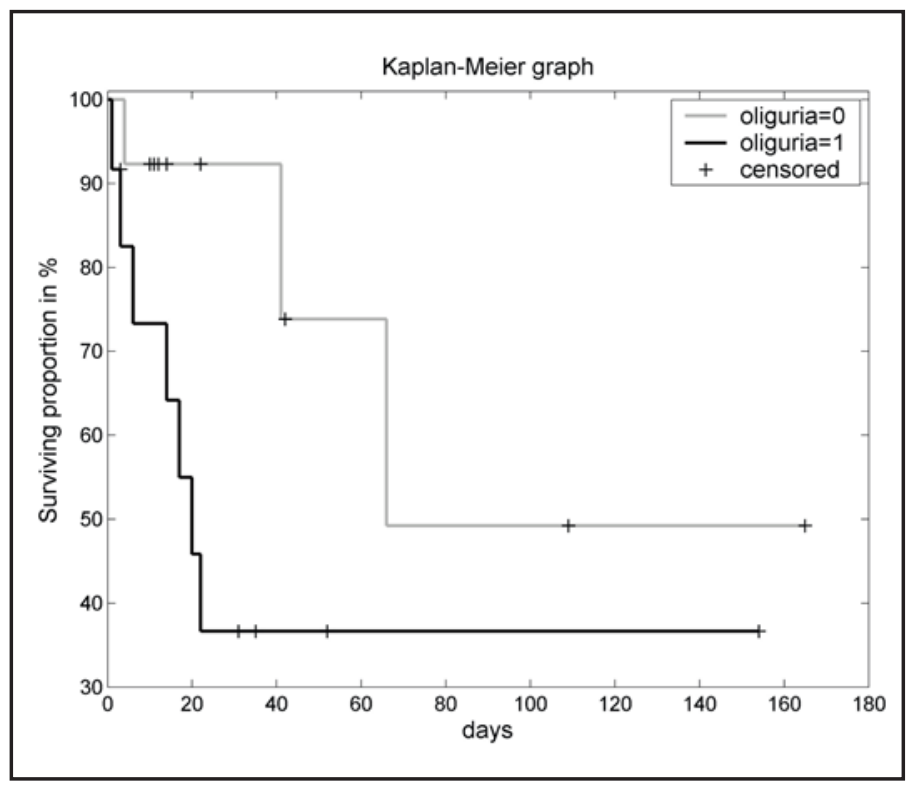

Fig. 2. The cumulative survival ratio of patients with AKI in PICU depending on the criterion of oliguria presence (defined as urine output $<0.5 \mathrm{ml} / \mathrm{kg} / \mathrm{h}$. / min. 16 hours).

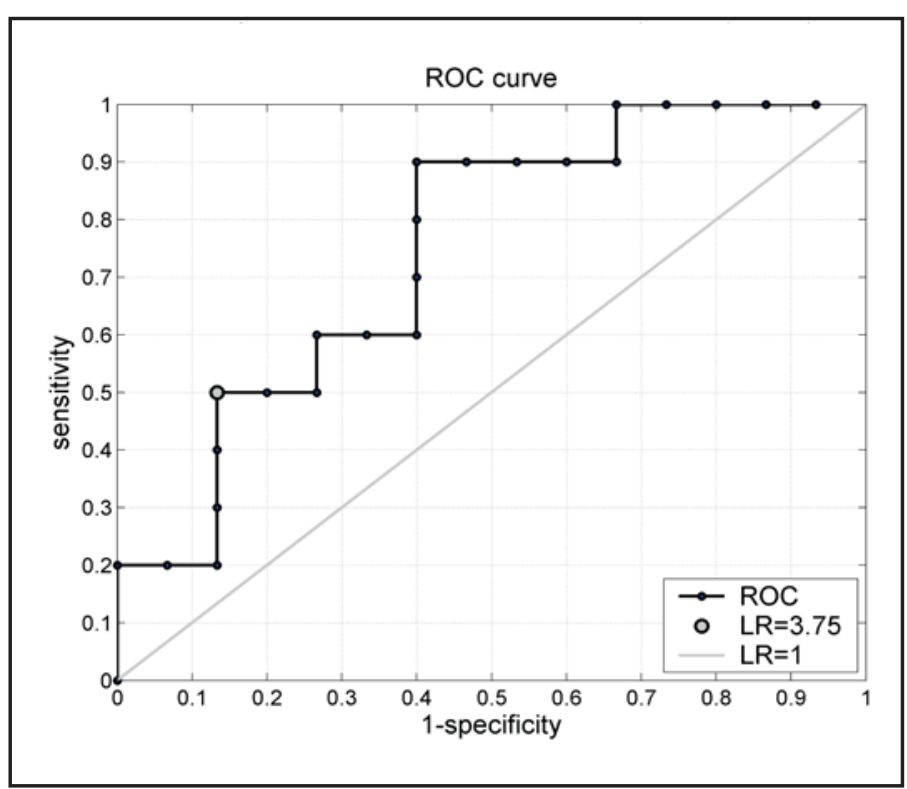

Fig. 3. The ROC curve plotted for the number of deaths as depending on the mean urine output value in the first week of hospitalization in PICU for all AKI patients; AUROC: 75\% for the selected cut-off value of $1.4 \mathrm{ml} / \mathrm{kg} / \mathrm{h}$, likelihood ratio (LR): 3.75; sensitivity: 50\%; specificity: $87 \%$. 


\section{Kidney \\ Blood Pressure Research}

Table 5. Comparison of selected clinical parameters of the surviving vs. deceased children with AKI

\begin{tabular}{|c|c|c|c|c|}
\hline Parameter & Deceased Patients & Surviving Patients & $\mathrm{pW}$ & $\mathrm{pt}$ \\
\hline Number of children (\%) & $10(40 \%)$ & $15(60 \%)$ & & \\
\hline $\begin{array}{l}\text { Mean age } \\
\text { [months]; [range] }\end{array}$ & $48.73+/-67.84[0.13-178.00]$ & $60.09+/-89.32[0.00-236.00]$ & NS & NS \\
\hline Mean body mass [kg]; [range] & $16.11+/-16.76[2.58-45.00]$ & $17.56+/-21.73[1.70-65.00]$ & NS & NS \\
\hline Primary diagnosis & $\begin{array}{l}\text { Hemato-oncologic diseases-5 } \\
\text { Gastroneterological diseases-3 } \\
\text { Nephrologic diseases - } 1 \\
\text { Cardiologic diseases - } 1\end{array}$ & $\begin{array}{l}\text { Cardiologic diseases -7 } \\
\text { Hemato-oncologic diseases-4 } \\
\text { Gastroneterological diseases-3 } \\
\text { Rheumatologic diseases -1 }\end{array}$ & & \\
\hline Most common secondary & MOF-6 & MOF-8 & & \\
\hline diagnosis (given patient & Sepsis-4 & Sepsis-4 & & \\
\hline $\begin{array}{l}\text { frequently had several secondary } \\
\text { diagnoses) }\end{array}$ & RCF-4* & RCF-7 & & \\
\hline $\begin{array}{l}\text { Mean number of days of } \\
\text { hospitalization in PICU +/-SD } \\
\text { [range] }\end{array}$ & $19.40+/-20.29[1-66]$ & $45.47+/-53.30[3-165]$ & NS & NS \\
\hline $\begin{array}{l}\text { Number and (\%) of children on } \\
\text { mechanical ventilatory support }\end{array}$ & $10(100 \%)$ & $13(86.7 \%)$ & NS & NS \\
\hline $\begin{array}{l}\text { Mean \% of ventilatory support } v s \text {. } \\
\text { duration of hospitalization in } \\
\text { PICU [range] }\end{array}$ & $\begin{array}{c}91.82 \%+/-21.51 \% \\
{[31.82-100 \%]}\end{array}$ & $\begin{array}{c}47.07 \%+/-33.26 \% \\
{[0.65-100 \%]}\end{array}$ & 0.001 & 0.001 \\
\hline $\begin{array}{l}\text { Dopaminergic medications- } \\
\text { number of children }(\%)\end{array}$ & $9(90 \%)$ & $13(86.7 \%)$ & NS & NS \\
\hline $\begin{array}{l}\text { Dopaminergic medications - } \\
\text { mean number of days when used } \\
\text { [range] }\end{array}$ & $12.78+/-6.92[3-20]$ & $12.00+/-7.13[1-21]$ & NS & NS \\
\hline $\begin{array}{l}\text { Adrenaline and noradrenaline - } \\
\text { number of children (\%) }\end{array}$ & $6(60 \%)$ & $5(33 \%)$ & NS & NS \\
\hline $\begin{array}{l}\text { Adrenaline and noradrenaline- } \\
\text { mean number of days when used } \\
\text { [range] }\end{array}$ & $7.00+/-6.69[1-18]$ & $5.80+/-3.83[1-10]$ & NS & NS \\
\hline pRIFLE: Mean day of I stage & $3[1-8]$ & $3,8[3-5]$ & NS & NS \\
\hline pRIFLE: Mean day of F stage & $4,1[1-16]$ & $4,2[1-17]$ & NS & NS \\
\hline $\begin{array}{l}\text { pRIFLE: F stage: } \\
\text { numer of children (\%) }\end{array}$ & $9(90 \%)$ & $12(80 \%)$ & NS & NS \\
\hline $\begin{array}{l}\text { Mean UO } \min [\mathrm{ml} / \mathrm{kg} / \mathrm{h}]+/-\mathrm{SD} \text {. } \\
\text { [range] }\end{array}$ & $0.52+/-0.72[0-1.80]$ & $1.00+/-0.85[0-2.54]$ & NS & NS \\
\hline $\begin{array}{l}\text { Mean UO } 1 \text { week }[\mathrm{ml} / \mathrm{kg} / \mathrm{h} .]+/- \\
\text { SD [range] }\end{array}$ & $1.49+/-1.15[0-3.24]$ & $2.57+/-1.33[0.05-4.39]$ & 0.043 & 0.047 \\
\hline $\begin{array}{l}\text { Oliguria (UO }<0.5 \mathrm{ml} / \mathrm{kg} / \mathrm{h} / \mathrm{min} \text {. } \\
16 \text { hours) - number of } \\
\text { children(\%) }\end{array}$ & $7(70 \%)$ & $5(33 \%)$ & $\mathrm{p}^{* *}=0.08$ & \\
\hline $\begin{array}{l}\% \text { of AKI duration vs. } \\
\text { hospitalization in PICU }\end{array}$ & $\begin{array}{c}79.77 \%+/-31.78 \% \\
{[15.00-100 \%]}\end{array}$ & $\begin{array}{c}46.19 \%+/-36.10 \% \\
{[2.60-100 \%]}\end{array}$ & 0.043 & 0.028 \\
\hline RRT - number of children & $7(70 \%)$ & $5(33 \%)$ & $\mathrm{p}^{* *}=0.08$ & \\
\hline $\begin{array}{l}\text { Mean duration of RRT +/-SD } \\
\text { [range] }\end{array}$ & $6.00+/-5.72[1-17]$ & $22.60+/-22.92[7-63]$ & 0.028 & NS \\
\hline
\end{tabular}

\section{Discussion}

The present study has included such factors as the prevalence, duration of hospitalization and mortality rates of patients with AKI, as well as AKI diagnosing based on the pRIFLE scale criteria depending on the employed initial value of SCr or eGFR.

According to various authors, the mean incidence of AKI (diagnosed based on the pRIFLE scale criteria) in PICUs falls within a very broad range, from $4.5 \%$ [16] to $82 \%$ [1] with the mean value being $49 \%$ (Table 6). In the seven year period of the study the diagnosis of AKI (code N17) was established only in 25 cases $(1.24 \%$ of the total number of PICU patients at this period which amounted to 2014), which seems to be a surprisingly low. The presented prevalence rate illustrates a situation when the above diagnosis was established monthly only in 0.3 patients treated in PICU or when a single case of AKI was diagnosed every 3.36 months. 


\section{Kidney Blood Pressure Research}

Table 6. AKI incidence, duration of hospitalization and mortality rates of children with AKI in PICU based on the literature and data collected in the present study

\begin{tabular}{|c|c|c|c|c|c|c|c|c|c|c|}
\hline & $\begin{array}{l}\text { Akcan- } \\
\text { Arikan et } \\
\text { al. } 2007\end{array}$ & $\begin{array}{l}\text { Bailey } \\
\text { et al. } \\
2007 \\
\end{array}$ & $\begin{array}{c}\text { Zappitelli } \\
\text { et al. } \\
2007 \\
\end{array}$ & $\begin{array}{l}\text { Plötz } \\
\text { et al. } \\
2008 \\
\end{array}$ & $\begin{array}{c}\text { Palmieri } \\
\text { et al. } \\
2009 \\
\end{array}$ & $\begin{array}{c}\text { Schneider } \\
\text { et al. } \\
2010 \\
\end{array}$ & $\begin{array}{c}\text { Kavaz } \\
\text { et al. } \\
2011 \\
\end{array}$ & $\begin{array}{c}\text { Bresolin } \\
\text { et al. } \\
2012 \\
\end{array}$ & $\begin{array}{l}\text { Hui } \\
\text { et al. } \\
2013 \\
\end{array}$ & PICU \\
\hline PICU AKI incidence & $82 \%$ & $4.5 \%$ & $75.7 \%$ & $58 \%$ & $45.5 \%$ & $10 \%$ & $33.3 \%$ & $46 \%$ & $56 \%$ & $1.24 \%$ \\
\hline Mortality: AKI & $14.60 \%$ & $27.30 \%$ & $55.40 \%$ & $25 \%$ & $8.90 \%$ & $30 \%$ & $32.30 \%$ & $36 \%$ & $21 \%$ & $40 \%$ \\
\hline Mortality: Controls & $11.10 \%$ & $2.50 \%$ & $8.80 \%$ & $5 \%$ & $1.50 \%$ & $3.70 \%$ & $9 \%$ & $3 \%$ & $2 \%$ & $9 \%$ \\
\hline AKI patients $* *$ & 22 & 10 & $\mathrm{nd}^{*}$ & 15.8 & 51 & 9 & 19 & 44 & nd & 35 \\
\hline No-AKI patients ** & 14 & 4.5 & nd & 13.6 & 18 & 2 & 9 & 23.2 & nd & 9.6 \\
\hline
\end{tabular}

${ }^{*}$ nd - no data; ${ }^{* *}$ Duration of hospitalization in days

A significant cause of a low frequency of diagnosing AKI is the fact that over 4 years, PICU fulfilled the role of the postoperative unit, what caused an increase in the total number of patients. Nevertheless, the undoubtedly dedicated medical staff should be more sensitive to the problems and epidemiology of AKI in PICU. Such a low frequency of diagnosing this complication may result from the fact that over the seven years in question, renal replacement therapy was required by 12 children only. Moreover, physicians are still convinced of the importance of maintaining UO, the notion being grossly overemphasized. This has been demonstrated in the present study, where the majority of newborns and infants $(10 / 16)$ already diagnosed with AKI still showed normal UO values. The value of hourly UO cannot be a reliable marker sufficient to diagnose AKI in the youngest children. Decreased UO starts to be of a diagnostics value only in children above 1 year of life which was noted in this study. A high importance of modified criteria in diagnosing AKI in the group of newborns was also found by Ricci et al. [17] and Bezerra et al. [18], who maintain the position advocating using the neonatal RIFLE scale, where the criterion of normal UO has been established as $1.5 \mathrm{ml} /$ $\mathrm{kg} / \mathrm{h}$, and stages $\mathrm{R}$ and I begin respectively at $\mathrm{UO}<1.5 \mathrm{ml} / \mathrm{kg} / \mathrm{h} / 24$ hours and $<1.0 \mathrm{ml} /$ $\mathrm{kg} / \mathrm{h} / 24$ hours.

The prevalence of establishing the diagnosis of AKI depending on the employed method of assessing the initial kidney function was analyzed in this study. In view of the very low number of patients in the studied population, it has not been possible to demonstrate differences in the prevalence of diagnosing AKI depending on the method of estimating the initial value of eGFR or SCr for the pRIFLE scale (Tab. 4). Irrespectively of the employed method, each diagnosed case met the criteria of AKI diagnosis. According to Zappitelli et al. [19], various methods of estimating initial eGFR determine the frequency of diagnosing AKI, with the percentage values dispersed from $12 \%$ to $88 \%$.

Nevertheless, even with such a limited clinical material in this study - the differences were found in the prevalence of diagnosing AKI based on the criterion of hourly urine output (UO $<0.5 \mathrm{ml} / \mathrm{kg} / \mathrm{h} / \mathrm{min} .16$ hours). The mean prevalence of diagnosing AKI based on the UO criterion for the total studied population of children was 48\% (Tab. 3, Tab. 4).

The issue of differences in the prevalence of diagnosing AKI in children hospitalized in PICU depending on the employed definition of initial kidney function is widely analyzed in the literature on the subject $[1,20]$. According to Akan-Arikan et al. [1], who - in case the value of SCr from the period up to 3 months prior to admission to PICU had not been available - estimated the initial kidney function in 150 children based on the assumption that normal GFR equaled $100 \mathrm{ml} / \mathrm{min} / 1.73$ sq. $\mathrm{m}$, the prevalence of AKI diagnosed based on the increase of SCr (in keeping with the pRIFLE scale) was $47.2 \%$, while when estimations were based on urine output, the relevant value was only $17.9 \%$. Similar results were obtained by Plötz et al., who adopted the same study conditions as Akan-Arikan et al. [1] in their population of 103 children. According to Plötz, the prevalence of AKI diagnosed based on an increase of SCr (pRIFLE) was 44.7\%, while when based on urine output, the value was only 5.8\% [20].

The low "diagnostic vigilance" in diagnosing AKI in the analyzed population of children as compared to the data from the literature is also supported by the fact that in the present 
study, as many as 21 children (84\%) were classified as stage F and only one child as the earliest risk stage (R) and three children as stage I (Tab. 3). Data from the literature addressing this issue are somewhat different.

Zapitelli et al. [21] analyzed a group of 140 children, whose initial kidney function - in case the value of SCr from the period up to 3 months prior to admission to PICU had not been available - was determined based on the assumption that normal GFR equaled $120 \mathrm{ml} /$ min/1.73 sq. $\mathrm{m}$. In this study, the prevalence of AKI diagnosed based on a decrease in eGFR in keeping with the pRIFLE scale was $75.7 \%$, with $35.7 \%$ being at the risk stage $\mathrm{R}, 22.1 \%$ at the injury stage I and only $17.9 \%$ at the failure stage F. Kavaz et al., who adopted the same study assumption, analyzed a group of 189 children, in whom AKI was seen in $35.9 \%$ of cases and demonstrated the following prevalence of particular pRIFLE stages: R - 7\%, I- 18.5\% and F - 9.6\% [22]. In the previously quoted study of Plötz et al., the investigators demonstrated that at the general AKI prevalence value of $58 \%$, as many as $52 \%$ of children reached the risk stage, $37 \%$ - the injury stage, and only $11 \%$ - the failure stage [20]. According to Washburn et al., in the population of 137 children, AKI was noted in $75.2 \%$ of patients; with the risk stage seen in as many as $36.5 \%$ of cases, the injury stage - in $20.4 \%$ and the failure stage - only in $18.3 \%$ of children [23]. In the reports of Bresolin et al. and Hui et al., in whom the initial kidney function in case the value of SCr from the period up to 3 months prior to admission to PICU had not been available was determined based on the assumption that normal GFR equaled $100 \mathrm{ml} / \mathrm{min} / 1.73$ sq. $\mathrm{m}$, the analysis included 126 and 140 children, respectively. The prevalence of AKI and the prevalence of its particular stages in the above investigations was $46 \%$ (R - 17.4\%, I - 16.7\%, F - 11.9\%) and 56\% (R - 23\%, I - 20\%, F - 12\%), respectively $[24,25]$. In the majority of the above quoted reports (excluding the papers by Plötz et al. [20]), the prevalence rates of particular pRIFLE stages referred to all the hospitalized children, nevertheless, a clear tendency towards stages R and I prevailing over stage F could be noted.

According to particular authors, the mean mortality rate in patients with AKI hospitalized in PICU ranges from 8.9\% [26] to 55.4\% [21] (mean: 28.5\%), being from 1.3 to 12 (mean: 10.2) times higher as compared to the general mortality rate in such units. In the presently analyzed group, $40 \%$ of the children died, the value being 4.4 times higher as compared to the total mortality rate in PICU (in the analyzed period, mortality among the children without AKI was $9 \%$; Tab. 6). Such a high mortality rate may result from the fact of assigning the N17 code (AKI) only to children with advanced disease, predominantly at the failure stage, therefore this study might not have included patients with earlier stages of AKI and this may explain the difference of the results in comparison with similar studies.

A similar conclusion arises following an analysis of the frequency of employing mechanical ventilatory support in children with AKI. In the analyzed group, mechanical ventilation was required by the mean percentage of $92 \%$ of the children, while according to various authors, the mean percentage of ventilatory supports in children with AKI ranged from $26.7 \%$ [26] to 63.8\% [24] (mean: 46.3\%), although there are reports confirming a $100 \%$ necessity of employing ventilators in the population of children with AKI [1].

According to the literature, the mean duration of hospitalization in AKI patients in PICU ranges from 9 [27] to 51 days [26] (mean: 25.8 days). In the present study, the mean duration of hospitalization in PICU was 35 days, what is consistent with literature data on the length of hospitalization in PICU for AKI patients. In regard to patients without AKI according to particular authors - their mean PICU hospitalization time ranges from 2 [27] to 23.2 [24] (mean: 12) days, being from 0.86 [20] to 2.8 [26] (mean: 2,3) times shorter as compared to the PICU length of stay of patients with AKI. In the presently analyzed group, the PICU hospitalization duration of patients without AKI lasted 9.6 days being 3.6 times shorter comparing to PICU duration of hospitalization of AKI patients, which is statistically significant $(\mathrm{p}<0.05$, Tab. 6).

Having performed our analysis exercising due diligence during the stage of material collection and statistical analysis of our results, we see the weak points of our study. We realize the study included a relatively small number of patients. In addition, it was retrospective and 


\section{Kidney \\ Blood Pressure Research}

addressed a single PICU. However the unit is located in a multi-specialist hospital enjoying the status of a referral center, with a heavy patient load and a wide spectrum of patients at various ages and with diversified initial diagnoses. Nevertheless, we believe that a detailed analysis of retrospective data has allowed for characterizing the epidemiology, course and prognosis of AKI, providing a starting point for interventions aiming at improving the prognosis of children treated in PICU.

\section{Conclusion}

The analysis of the results allows for formulating the following conclusions:

1. Oliguria is not a reliable marker sufficient for diagnosing AKI in children below 1 year of life.

2. The risk of death in children, in whom the mean urine output in the first week of hospitalization in PICU did not exceed $1.4 \mathrm{ml} / \mathrm{kg} / \mathrm{h}$ is almost two times higher as compared to the total population of hospitalized AKI children.

3. A retrospective analysis of the course of the disease and treatment employed in PICU confirm the fact that in many cases, acute kidney injury was diagnosed too infrequently and too late.

\section{Disclosure Statement}

The authors declare that there are no conflicts of interest.

\section{References}

1 Akcan-Arikan A, Zappitelli M, Loftis LL, Washburn KK, Jefferson LS, Goldstein SL: Modified RIFLE criteria in critically ill children with acute kidney injury. Kidney Int 2007;71:1028-1035.

-2 Bunchman TE, McBryde KD, Mottes TE, Gardner JJ, Maxvold NJ, Brophy PD: Pediatric acute renal failure: outcome by modality and disease. Pediatr Nephrol 2001;16:1067-1071.

3 Fargason CA, Langman CB: Limitations of the pediatric risk of mortality score in assessing children with acute renal failure. Pediatr Nephrol 1993;7:703-707.

-4 Goldstein SL, Currier H, Graf CD, Cosio CC, Brewer ED, Sachdeva R: Outcome in children receiving continuous venovenous hemofiltration. Pediatrics 2001;107:1309-1312.

-5 Goldstein SL, Somers MJ, Baum MA, Symons JM, Brophy PD, Blowey D, Bunchman TE, Baker C, Mottes T, McAfee N, Barnett J, Morrison G, Rogers K, Fortenberry JD: Pediatric patients with multi-organ dysfunction syndrome receiving continuous renal replacement therapy. Kidney Int 2005;67:653-658.

6 Coca SG, Peixoto AJ, Garg AX, Krumholz HM, Parikh CR: The prognostic importance of a small acute decrement in kidney function in hospitalized patients: a systematic review and meta-analysis. Am J Kidney Dis 2007;50:712-720.

7 Goldstein SL, Denfield S, Mott A, Chang A, Towbin J, Dickerson H, Dreyer J, Price J: "Mild" renal insufficiency is associated with poor outcome in children with acute decompensated heart failure: Evidence for a pediatric cardiorenal syndrome [abstract]. J Am Soc Nephrol 2005;16:3365-3370.

8 Ball EF, Kara T: Epidemiology and outcome of acute kidney injury in New Zeland children. J Paediatr Child Health 2008;44:642-646.

-9 Cerdá J, Lameire N, Eggers P, Pannu N, Uchino S, Wang H, Bagga A, Levin A: Epidemiology of acute kidney injury. Clin J Am Soc Nephrol 2008;3:881-886.

10 Askenazi DJ, Bunchman TE: Pediatric acute kidney injury: The use of the RIFLE criteria. Kidney Int 2007;71:963.

-11 Askenazi DJ, Ambalavanan N, Goldstein SL: Acute kidney injury in critically ill newborns: What do we know? What do we need to learn? Pediatr Nephrol 2009;24:265. 


\section{Kidney \\ Blood Pressure Research}

\begin{tabular}{|c|c|}
\hline Kidney Blood Press Res & \\
\hline $\begin{array}{l}\text { DOI: 10.1159/000355774 } \\
\text { Publisnea onine: 1viray 09, } 2014\end{array}$ & $\begin{array}{l}\text { (c) } 2014 \text { S. Karger AG, Basel } \\
\text { www.karger.com/kbr }\end{array}$ \\
\hline
\end{tabular}

12 Schwartz GJ, Furth SL: Glomerular filtration rate measurement and estimation in chronic kidney disease. Pediatr Nephrol 2007;22:1839-1848.

13 Ozçakar ZB, Yalçinkaya F, Altas B, Ergün H, Kendirli T, Ateş C, Elhan AH, Ekim M: Application of the new classification criteria of the Acute Kidney Injury Network: a pilot study in a pediatric population. Pediatr Nephrol 2009;24:1379-1384.

14 Sztefko K: Biuletyn norm laboratoryjnych Uniwersyteckiego Szpitala Dziecięcego. Department of Clinical Biochemistry, University Children's Hospital of Cracow. Kraków, 2010;1:1-63.

15 Pottel H, Mottaghy FM, Zaman Z, Martens F. On the relationship between glomerular filtration rate and serum creatinine in children. Ped Neph 2010;25:927-934.

-16 Bailey D, Phan V, Litalien C, Ducruet T, Mérouani A, Lacroix J, Gauvin F: Risk factors of acute renal failure in critically ill children: A prospective descriptive epidemiological study. Pediatr Crit Care Med 2007;8:29-35.

17 Ricci Z, Ronco C: Neonatal RIFLE. Nephrol Dial Transplant 2013; 28: 2211-2214.

-18 Bezerra CT, Vaz Cunha LC, Libório AB: Defining reduced urine output in neonatal ICU: importance for mortality and acute kidney injury classification. Nephrol Dial Transplant 2013;28:901-909.

19 Zappitelli M, Parikh CR, Akcan-Arikan A, Washburn KK, Moffett BS, Goldstein SL: Ascertainment and epidemiology of acute kidney injury varies with definition interpretation. Clin J Am Soc Nephrol 2008;3:948-954.

20 Plötz FB, Bouma AB, van Wijk JA, Kneyber MC, Bökenkamp A: Pediatric acute kidney injury in the ICU: an independent evaluation of pRIFLE criteria. Intensive Care Med 2008;34:1713-1717.

21 Zappitelli M, Washburn KK, Arikan AA, Loftis L, Ma Q Devarajan P, Parikh CR, Goldstein SL: Urine neutrophil gelatinase-associated lipocalin is an early marker of acute kidney injury in critically ill children: a prospective cohort study. Crit Care 2007;11:R84.

-22 Kavaz A, Ozçakar ZB, Kendirli T, Oztürk BB, Ekim M, Yalçinkaya F: Acute kidney injury in a paediatric intensive care unit: comparison of the pRIFLE and AKIN criteria. Acta Paediatr 2012;101:e126-129.

-23 Washburn KK, Zappitelli M, Arikan AA, Loftis L, Yalavarthy R, Parikh CR, Edelstein CL, Goldstein SL: Urinary interleukin-18 is an acute kidney injury biomarker in critically ill children. Nephrol Dial Transplant 2008;23:566-572.

24 Bresolin N, Bianchini AP, Haas CA: Pediatric acute kidney injury assessed by pRIFLE as a prognostic factor in the intensive care unit. Pediatr Nephrol 2013;28:485-492.

25 Hui WF, Chan WK, Miu TY: Acute kidney injury in the paediatric intensive care unit: identification by modified RIFLE criteria. Hong Kong Med J 2013;19:13-19.

-26 Palmieri T, Lavrentieva A, Greenhalgh D: An assessment of acute kidney injury with modified RIFLE criteria in pediatric patients with severe burns. Intensive Care Med 2009;35:2125-2129.

27 Schneider J, Khemani R, Grushkin C, Bart R: Serum creatinine as stratified in the RIFLE score for acute kidney injury is associated with mortality and length of stay for children in the pediatric intensive care unit. Crit Care Med 2010;38:933-939. 